\title{
Free Voluntary Reading And The Role Of The Teacher Librarian
}

\author{
Susan La Marca \\ Melbourne \\ AUSTRALIA
}

\begin{abstract}
This paper attempts to do three things: Investigate recent research that outlines a relationship between free voluntary reading. or pleasure reading, and student achievement. Link these findings to my own research into the role of the teacherlibrarian in creating a positive reading environment, and Detail some of the programmes and initiatives that can support us in engaging students with their reading.
\end{abstract}

\section{Free voluntary reading and student achievement - Recent research}

Alberto Manguel, in his beautiful book, A History of Receding said: "We all read ourselves and the world around us in order to glimpse what and where we are. We read to understand, or to begin to understand." (Manguel, 1996, p. 7).

For many of us who are passionate about books this is reason enough for us to read and to encourage our school communities to foster reading as part of the school curriculum and as part of everyone's lives. For those of us who see reading as crucial, the thought of making it part of what we do goes without saying. The importance of reading in the lives, and education, of children is understood. Michacl Rosen outlined the important place of reading to learning. He said:

What children learn with books is a whole initiation into such matters as: how do you know whether you are reading a story or a factual report, how do you know if someone in a story is telling the truth, how do bour learn to plat an author's game of hegin tricked by red herrings, seduced by charmers, repelled by the wicked and much, much more. In fact, most, if not all, the reading we do as adults rests on the bedrock of having learned as children the devices and techniques of narrative that have heen developed over thousands of gears in literature. (Rosen. 199.5)

Another, more pragmatic, view is that "Reading literacy is needed to function well in adult life, whether in fulfilling personal goals, progressing in the labour market or participating more widely in society." (OECD, 2000, p. 3).

Reading is both an important skill that enables us to function effectively in society, and an experience that increases our understanding of the world around us. It can open windows for us into other experiences both real and imagined.

Both of these functions of the business of reading are relevant to education. But the idea that reading has intrinsic benefits that, though difficult to assess or determine, cannot be discounted, is a view that does not always hold sway in the realm of educational debate. 
Certainly, in Australia, in today's educational debate, 'scores on the board' often rule decision-making. It is those activities that have a recognised impact on student achievement that will garner more funding, more staff and more administrative support. If teacherlibrarians, as educators, are going to argue the relevance of free voluntary reading as an activity to be encouraged and supported, we must look to research evidence to support our often heart-felt belief that reading for pleasure matters.

So, let's play that game. Why should we encourage students to read'? Why should we take up valuable curriculum time encouraging students to make reading part of their lives? Why encourage them to read for themselves, for pleasure, in their own time?

In the remainder of this section I will consider six different reports, or reviews of research, that make an argument linking free voluntary reading to student achievement.

\section{Impact of school libraries on student achievement: $A$ review of the research by Dr. M. Lonsdale. A report produced for the Australian School Libraries Association.}

During 2003, the Australian School Library Association (ASLA) released the report Impact of School Libraries on Student Achievement: a Review of the Research. This report is an overview of research that has been conducted in relation to school libraries and student achievement and made recommendations in relation to the profession within Australia. Dr Michelle Lonsdale prepared the report for ASLA in conjunction with the Australian Council for Educational Research. The report found: "A print-rich environment leads to more reading and free voluntary reading is the best predictor of comprehension, vocabulary growth, spelling and grammatical ability and writing style." (Lonsdale, 2003, p.1).

Such findings are replicated across much of the research discussed in this paper. The obvious link between free voluntary reading, or pleasure reading, and basic curriculum areas such as vocabulary and spelling, makes a strong case for incorporating the encouragement of free voluntary reading as a standard practice within any curriculum.

\section{Trends in academic progress: Three decades of student performance by Campbell, Hombo, and Mazzeo. Produced by the National Assessment of Education Progress, Department of Education, Washington DC.}

The American National Assessment of Education Progress report investigated the link between free voluntary reading and text scores in reading and also found an obvious. irrefutable link:

[The] 1999 long-term reading assessment found that reading for fiun had a positive relationship to average scores. At all three ages 19, 13, 17 vears), students who said they read for fin scored higher than peers who said they never read for fiun. (Camphell, J. R., Hombo, C. M., \& Mazzeo, J., 20(0)). 
Independent reading and school achievement by $B$. E. Cullinan. Commissioned as part of a national study - Assessment of the role of school and public libraries in support of educational reform

This American report was part of a national study into educational reform. It found that: "The common sense notion that students who do a substantial amount of voluntary reading demonstrate a positive attitude toward reading is upheld in both qualitative and quantitative research". (p.1)

It went on to describe similar findings from available research:

The amount of free reading done outside school has consistently been foumd to relate to growth in vocabulary, reading comprehension, verbal fluency; and general information (Anderson, Wilson, and Fielding 1988; Greaney 1980); Gurthrie and Greaney 1991; Taylor, Frye, and Marturama 1990). Students who read independently become better readers, score higher on achievement tests in all subject areas, and have greater content knowledge than those who do not. (Krashen 1993; Cunningham and Stanovich 1991; Stanovich and Cunningham 1993). (p.2)

The conclusion of this report states:

Independent reading is the kind students choose to do on their own; it is not assigned or assessed, but it has a positive effect on learning and school achievement. Research about the effects of independent reading on school achievement and programmes planned to promote it demonstrates these common factors:

The amount of fiee reading done outside school has consistently been found to relate to achievement in vocahulary, reading comprehension, verbal fluency. and general information.

Students' reading achievement correlates with suceess in school and the amount of independent reading they do." (Anderson. Wilson and Fielding 1988; Guthrie and Greaney 1991; Krashen 1993; Cumningham and Stanovich 1991; Stanovich and Cunningham 1993). (p.8), and

Common features of effective programmes designed to promote reading in schools, homes, and libraries include access to varied material that appeals to all ages and tastes, active parent involvement, partnerships among community institutions, and collaboration among significant adults in students' lives (p.8)

This report comments that such a relationship is problematic, but the relationship is definitely apparent. While we must be aware that the causal relationship between reading and achievement is difficult to discern, this should not disallow us from recognising that the two are closely linked and perhaps, as educators, it is a relationship that we should aim to explore and foster to the benefit of our students.

\section{Start with the child: Report of the CILIP Working Group on library provision for children and young people, Chartered Institute of Library and Information Professionals.}

This British report was prepared for the public library sector. It makes a number of important statements that are also relevant to the school library sector. It recognises the link 
between the quality of learning and student achievement in schools and the relationships between library staff and teaching staff. This link, and the overall importance of all relationships to the creation of a reading environment in schools, is something that my own research highlights and that I will outline further in the next section of this paper. From the executive summary of this report, under the heading Libraries, reading, literacy and learning, the following point was made: "Research shows that the relationship between school librarians and teachers has a significant impact on the quality of learning in schools. Better integration, mutual understanding and respect need to be developed." (section 3.10)

\section{The crisis of Canada's school libraries: The case for reform and re-investment By Dr Ken Haycock, Association of Canadian Publishers.}

This very important report by Dr Ken Haycock outlines research findings in relation to the current status of school libraries in Canada. Haycock, whilst making them same links between reading and school achievement, says that, "Studies connecting teacher-librarians and school libraries with achievement in reading have been available for more than 50 years." (Haycock, 2003, p. 17), and "The positive correlation among teacher-librarians, libraries and reading - ability to read, motivation to read, quantity read, results on reading assessments has been true across grade levels, socio-economic class, urban/rural areas and across several decades." (Haycock, 2003, p.26)

Haycock also recognises other areas within which school libraries may have an impact. He found that "...school libraries and teacher-librarians contribute to achievement, literacy and culture." (Haycock, 2003, p. 13) and that "..school libraries expose children from low-income neighbourhoods to reading materials they may not otherwise have access to." (Haycock, 2003, p.15)

Not only, then, can school libraries contribute to achievement through the promotion of free voluntary reading, they also have a role to play in exposing children to their own and other cultures and in assisting with making access more equitable through providing library services in disadvantaged areas. These important findings serve to reinforce the role that libraries can play in extending the experiences of students, particularly through reading promotion.

Haycock recognises the 'special' role of the library above the other book collections to be found within the school: "In other words, classroom collections should not be seen as a substitute for centralised school libraries." (Haycock, 2003, p.29)

He also notes the importance of the library as a welcoming, positive environment: "The physical ambience of the school library is a relevant factor in terms of the library programme's overall impact on student achievement and literacy." (Haycock, 2003, p.23).

Both of these factors are linked to how the library provides access and creates an environment that promotes and encourages free voluntary or pleasure reading.

\section{Reading for change: Performance and engagement across countries. Results form PISA 2000, OECD - PISA}

Finally I would like to consider an important OECD report that I would encourage you all to download and read for yourself. It was conducted in 32 countries and involved over 
260,000 students. The report considers reading literacy levels across the 32 countries and the different types of reading that students are required to perform. These research findings make the same link between free voluntary reading and achievement. They then take the extra step of establishing the key factor in why students might become readers and continue to be readers.

The report identifies student engagement as the key, and says: "Students who read well tend to be active readers. They gain in terms of both motivation and experience from reading regularly outside the context of school work." (OECD, 2000), p.12)

In discussing how engagement can be facilitated, the report recognises the school as one area we may have influence over, in comparison family behaviour is more difficult to influence, the report says:

[The] way in which schools are organised, are more amenable to change. One crucial factor that education ststems can work on is the degree to which students are active and well motivated readers. This report shows that the degree to which students are engaged in reading is a cructal factor associated with receding proficiency. (OECD, 2000), p.3)

and, "The results show how important it is not just to teach students to read but to engage them in reading as part of their lives." $(\mathrm{OECD}, 200), \mathrm{p} .12)$

Engagement is the key. Engaging students with books that they want to read. Making reading an experience that they will want to continue in their own time. The report found that: "In most countries, there is a strong or at least moderate relationship between engagement and performance." (OECD, 2000, p.12).

If we see engagement as the key, we have some serious questions to ask ourselves. As graph one from the Receding for Change report illustrates there are a number of countries with low levels of student engagement.

Is our curriculum, and the way we handle the reading experience designed to encourage student's enjoyment of reading?

Are we predominantly interested in engaging students with texts?

Or do we emphasise analysis, assessment and scores at the expense of fun and engagement?

Does the library have a central role in engaging students in reading as an activity?

Are our libraries providing the reading material they enjoy"?

Does our treatment of reading in schools make it pleasurable?

Do our teaching practices give students time to relish and share their reading'?

Do we model well enough as a community the pleasure and gain to be had from the reading experience? 


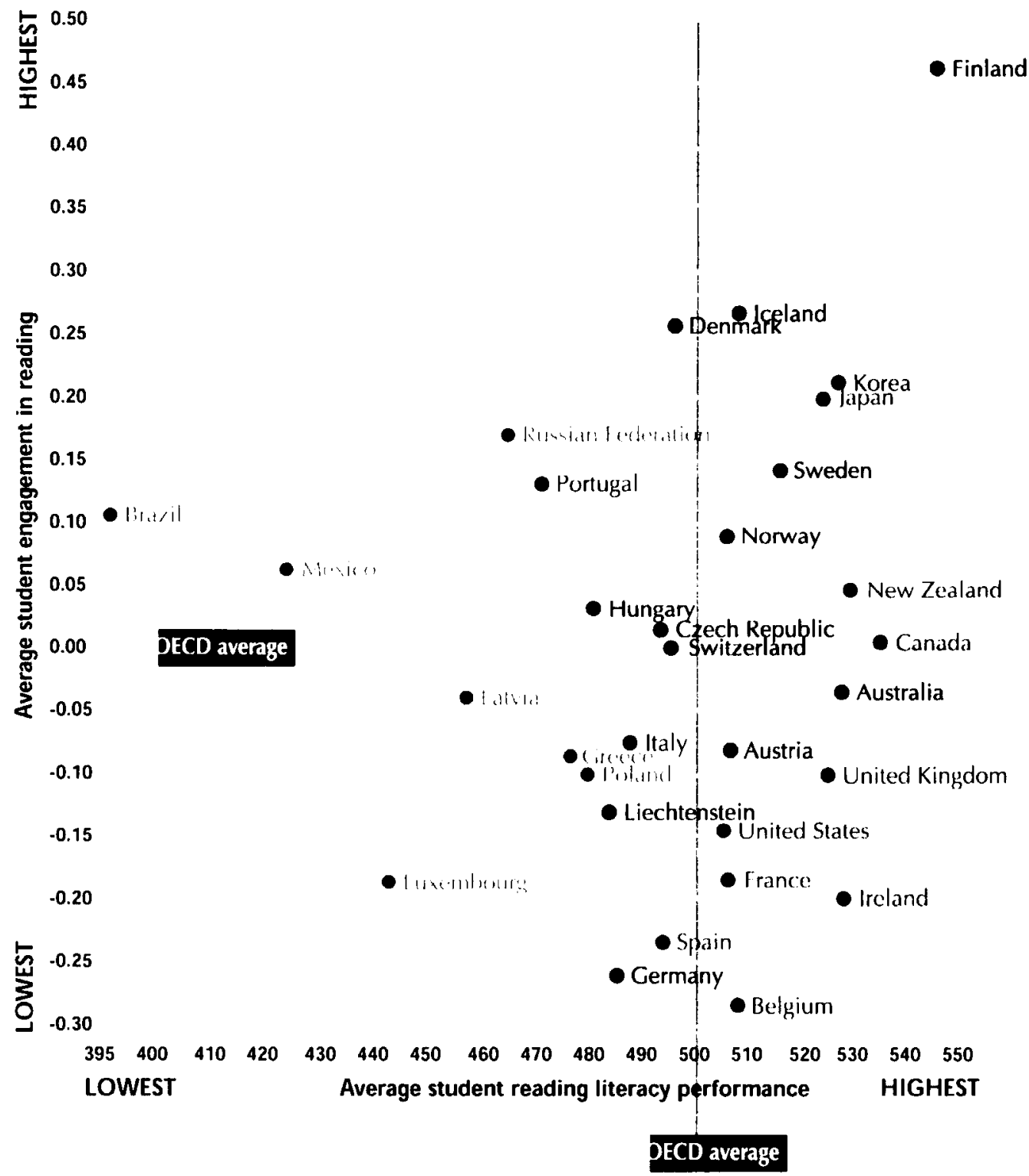

Figure 1: Measuring student engagement PISA (OECD, 2000, p. 13)

All of these may be possible reasons for the reported low levels of engagement in some countries but not one of these questions has an easy answer. The answers, and the questions we need to ask, will be different for each school community that each of us works within.

On a school level, what can we do to improve this scenario?

I would argue that it can begin with our profession. There is a place for teacherlibrarians as enabling adults, stimulating and supporting an interest in reading as a worthwhile pleasure activity. 


\section{In summary}

What all of these reports agree on is the obvious link between the practice of reading and increased levels of achievement.

Such overwhelming research is strong evidence for a place within schools for reading for pleasure. This is evidence that you can take to your school administration in your own endeavours to make the library central to your school as a reading community. More funding for collection building, to establish and expand wider reading programmes and create libraries that are welcoming, effective reading environments is necessary to enable students to make reading part of their lives.

\section{Enabling Adult: the teacher librarian}

To make this happen we need to be enabling adults

My own case study research investigated the contextual and attitudinal factors that influence how a teacher-librarian creates a reading environment in a secondary school library (La Marca, 2003).

The most important factor identified was attitude.

- The attitude of the teacher-librarian to reading as a pleasure activity and as a part of the school curriculum.

- The attitude of the teacher librarian towards students as readers. Are the students seen as an equal part of a reading community, or as second-rate readers with tastes and views below that of adults'?

- And the attitude of teacher librarians to their own role in reading promotion. Do they perceive it be part of their role or is it someone else's responsibility?

Zahnleiter said: "Children learn about literature from what the adults around them do about it." (Zahnleiter, 1985, p187)

Our attitudes towards all aspects of the reading environment fuel the way reading is perecived by students. Whilst we have the power to create reading environments through a positive view of our role we can also be destructive as a number of the case studies in my own research showed (La Marca, 2003). found:

Many commentators also recognise the power of attitude. Williams, Wavell and Coles

Studies which consider particular learning aspects of the school library ofien mention the experience and attitude, personality and commitment of the school librarian in relation to the activities and it is clear from the literatere that this is of fundamental importance. (Williams, Wanell and Coles. 2001, p25)

Phillips said, "The three great intangibles of school librarianship are image, personality and atmosphere. The three are interrelated, but in probably no other profession are they so important. Image is elusive." (Phillips, 1988, p25). 
The Cullinan report found that similar importance could be placed upon the attitude of teachers:

Bertland (1988), found that student' patterns of borrowing books firom the library for recreational reading hinge on the attitudes of their teachers. Teachers who consistently bring their classes to the library for skills lessons and to do content-area research have students who frequently use the library for independent reading. On the other hand, teachers who do not bring their classes to the libray to select books have students who check out fewer books per person. (Cullinan, 2000), p.3)

Attitude is strongly linked to relationships, which is another of the key factors that my research investigated and found to be crucial in the creation of an effective reading environment. Hartzell said, "Teacher librarians must work on building relationships as consciously as they work on building collections." (Hartzell, 1999)

The relationships we form with teaching staff, with students and with administration are all integral to the form of the environment we create. Successful programmes and initiatives are usually built on a solid base of good supportive relationships. Destructive relationships, however, demonstrated little collegiate support and very few shared goals, resulting in poor reading environments.

Whilst these are only the two main areas highlighted in my research into how a teacher-librarian creates a conducive reading environment in schools, they are the most important of a number of interconnected, interactive factors that attempt to explain and explore what takes place in any given school library. Time constraints, unfortunately, do not allow a more expansive exploration in this paper.

I would like to move now to explore briefly the concept of the teacher-librarian as an enabling adult. In a practical, every-day sense, how are we Enabling Adults?

Aidan Chambers originally used the concepts of an enabling adult and the reading environment in his inspiring book, The Reading Environment. He said:

What is it that enabling adalts, teachers especially, do? They provide, stimulate, demonstrate and respond. They provide books and time to read them and an attractive environment where people want to read. They stimulate a desire to become a thoughtfil reader. They demonstrate by reading aloud and their own behaviour what a 'good' reader does. And ther respond, and help others respond, to the individuality of everyone in the reading community. they belong to. (Chambers, 1991, p.92)

What is needed to create a positive reading environment? What does the enabling adult do? My work indicated that to be successful there should be:

- a large, varied collection of reading materials.

Haycock agrees saying that.

"It should come as on surprise that if reading is valued and promoted, voung people will need interesting and relevant material to read. Access to these materials becomes critical. Further, the larger the library collection, the larger the impact on reading and achievement." (Hancock, 200)3, p.28) 
- Knowledgeable library staff who know both the collection and the students with whom they work

Carter saw the value of this role. He said, "In order to become lifelong readers, children must have access to books - and lots of them. They must also have some help in selecting them. Librarians call that help readers' advisory, and it's an art." (Carter, 2000, p3).

- adequate access to reading materials both during structured reading programmes and out of school hours

Krashen, in his important book The power of reading (1993), outlined the importance of access. In a later article he said, "There is a great deal of evidence showing that children with more access to books read more." Krashen, 2002, p2).

- varied forms of reading materials in an array of reading ability levels

- time within the curriculum just for reading

- opportunities for book discussion experience.

Chambers stresses the power of talk, of 'book gossip' to enrich and extend the reading

- modelling by staff of positive attitudes towards reading and their students as readers

Chambers has said, "Readers are made by readers." (Chambers, 1991, p87)

My own work reinfored this view. The powerful influence of schools and their staff over the views and attitudes of students cannot be discounted.

- whole school support for reading as a necessary part of life

- an encouraging, welcoming physical environment

Haycock found that "A good reading environment, including comfort and quiet, as well as larger library collections, affects reading, literacy development and reading scores." (Haycock, 2003, p.30)

- a sense of ownership by the students of their own reading development and their reading environment

\section{Programmes and initiatives to engage students as readers}

In this section I will briefly outline some initiatives that fulfil the requirement of engaging students, on their terms, in reading as an activity. For each there are references and further reading detailed in the reference list.

\section{Classroom experiences}

The class study of one novel as a reading experience is perhaps more maligned than any other reading activity in terms of how it encourages and enthuses students to become interested readers in their own time. Much of the traditional study of one text in the classroom ignores what we know about how students enjoy and respond to reading as an 
activity. From the student viewpoint, the study of one text by the entire class is often not an enjoyable experience for a variety of reasons.

I would like to report on three variations to the standard approach that go some way towards changing the traditional structure of class text study. Each incorporates aspects of the ideas put forward in the two previous sections of this paper.

\section{Choice of text}

This approach has been operating for some years at Ivanhoe Girls' Grammar School in Ivanhoe, Melbourne.

With this variation all English classes at a particular year level need to be time-tabled together. Each English teacher then chooses a book to teach, about which he or she is particularly passionate. Students may then select which book they wish to study across all of the English classes on offer during that block. This, as with the literature circles approach outlined below, offers greater choice for the students.

Teaching staff have a level of freedom to allow them to work at their best and they can be assured, within normal minimum class number constraints that the students who are in their class to work with a particular book have chosen to be there. There is also the possibility that a wide range of text types and varied levels of difficulty amongst those texts could be offered, opening up the opportunity for students to find a learning experience on offer that best meets their needs. Anecdotally it is reportedly that the students find the increased level of choice liberating. Whilst this approach still has a whole-class/teacher-centred focus on a single text, it does allow for some student centred choice and, subsequently, a greater level of engagement from all participants.

\section{Mini sets / Literature circles}

Literature circles (Daniels, 2002) and mini sets (Last \& McNamara, 1999) allow the students to work in small groups. This approach allows the students input into the choice of book that they will discuss from amongst, in most cases, a selection of titles bought specifically for this purpose. Literature circles, specifically, through the role structure for discussion, offer some control for students over how they will respond to, and interact with, a book. These options increase the level of choice available to the students, allowing them a sense of ownership of the reading experience and, hopefully, a greater feeling of engagement. Smaller groups are also less intimidating and much more closely aligned to a 'real' book discussion amongst a friendship group, thus allowing more chance for a positive reading experience. Variations on this general theme are various Hunter (2003) discusses the various approaches in a number of Melbourne schools and Sutherland (2003) discusses an interesting variation using pairs rather than small groups.

\section{No text approach}

Clayton Massey of Perth, Australia has spoken often now on the approach that he developed some years ago to overcome the lack of interest of his students, and disenchantment of his staff, with the experience of class work on texts and reading in general. Massey (2003) was intent on empowering his students. In essence, Massey replaced the 
booklist for English with a fee or levy. He then introduced the concept of free choice in reading material for class and acknowledged the validity of all forms of text, particularly nonfiction. Students choose a book for themselves from a local bookshop and this choice was then purchased for them with the levy funds. This book was theirs to keep. Massey constructed a number of team-based competitive activities to stimulate activity and interest in reading based on a number of sel concepts rather than one specific classroom text.

Such an approach embraces choice and a sense of ownership by students of their own reading. In the elassroom it relies on open-ended tasks, higher order questioning and a focus on concepts rather than one particular text. It also recognises the range of difference amongst the student cohort, allowing students to choose a book that best suits their specific needs.

\section{The role of the teacher-librarian}

Within all of these modifications to the traditional elassroom approach of studying text there is a role for the teacher-librarian as the ultimate enabler of choice. A good, broad library collection and a welcoming library environment could be built into each of these approaches as an extension of the underlying principles. Choice from a wide range of materials, small group work and an interest in difference of all kinds are best facilitated with the support of a well-functioning school library and the teacher librarian as an enabler of the process.

\section{Library experiences}

Only imagination and resources limit the range of activities that may be offered through the library to facilitate the reading experience. Support for, and extension of, the classroom experience is essential but a great deal can be done through the library to promote the library space as a reading environment.

Haycock (2003) reported that:

Teacher-librarians typically place the right book in the right hands at the right time and encourage a lifelong love of receding (Barlup, 1991). The role of the reacher-librarian. connecting young people with books that interest them. has been underestimated. (p. 27).

This is a very empowering statement. This is a role, that of reader's advisor, that we should we take very seriously. As enabling adults we have the collection at our fingertips. We are the ones that build a collection, have an in-depth knowledge of that collection, facilitate access and create a welcoming reading environment that is conducive to students returning again and again.

Some possible activities that can be initiated by the library include:

- Wider reading programme in corporation with English Department

- Book raps or MOOs (synchronous virtual discussion) online

- Book clubs for students (Book clubs, 1999)

- Discussion groups for staff and parents 
- Competitions

- Celebratory days, weeks or festivals

- Displays - particularly those constructed by students (Hart. 2001)

- Excursions

- Book selection and buying activities

- Guest speakers - authors, storytellers, illustrators

- Lists and guides to facilitate selection

- Promotional programmes, reward systems

Any activity that encourages interest, enables students to come into contact with books and offers them the experience of reading as a pleasurable activity is worthwhile. The type of activity will vary depending on the teacher-librarian's own interests, strengths and capabilities.

In elosing I would hope that I have made an argument for, and outlined research evidence that supports, the following:

- the place of free-voluntary reading

- the need to engage students in the reading experience

- and the role of teacher-librarian as an enabling adult.

\section{References}

Association for Supervision and (urriculum Development (ASCD). (2003). School Libraries and Their Impact of Student Performance, U.S.A.. (Online Report) Available at:

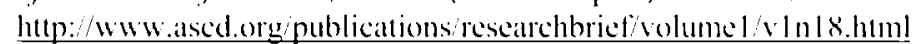

'Book clubs' (1999). Chapter with various contributors. In Susan La Marca (Ed.) Back wo books: (recting a foctus on fiction (volume 2), Carlton, Vic: School Library Association of Victoria.

Book raps An introduction to book raps: http://Www.schools.sh.org.au/jstubbs bookrap.htm (or to participate: http:/rite.ed.cut.au/old or-teachernet/projects/book-rap/indexl html

Campbell. J. R.. Hombo, C. M., \& Mazzeo. J. (2000). 1999 Trends in Academic Progress: Three Decodes of Stuckent Performance (online report) NAEP (National Assessment of Fducation Progress) Washington DC: Department of Education. Available at: www.nill.gov/nifl facts/reading-facts.html

(arter. B. (2000). Reoding levels and Readahility. Formulas do not Create Lifelong Readers, [online website].

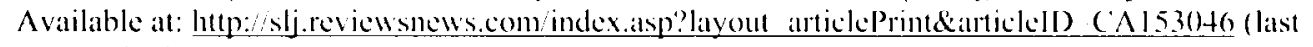
accessed 7 th June 2003).

('hambers, A. (1991). The Reading Environment. NSW: PETA. Thimble Press.

('hambers, A. (1993). Tell Me: Children, Reculing and Talk, NSW: Pl:TA. Thimble Press.

(hartered Institute of Library and Information Professionals (CILIP) (2002). Start with the (hild: Repent of the ('ILIP Working Group on Lihray Provision for Children and Youmg People (Online report) London: CILIP. Available at: www.cilip.org.uk

(ullinan, B. I. (2000). Independent Reeding and School Achio'sement. This manuscript was commissioned as part of a national study - Assessment of the Role of School and Public Libraries in Support of Educational Reform. (Originally prepared for the U.S. Department of Education). New York: American Library Association. Available at:

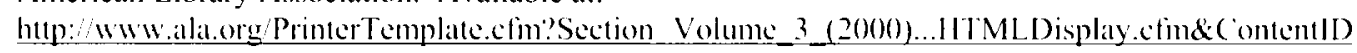
2523

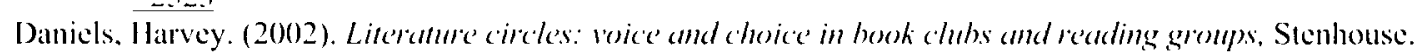
More information and opportunities available at: www. literalturecircles.coms

Hart, Kate. (2001). 'Aturacting the Audience: Display” in Susan La Marca (Ed.) Bonks up) Frome: Imesting in the' l'alece of Reading, Carlton. Victoria: SLAV. 
Hartzell, G. D. (1999). The Principal - Teacher Librarian Relationship as a Ke'y to Influence and Success. Available at: www.csu.edu.au/rescarch/estl/isis/participants/papers/A-Hlartzell ([Accessed Nov 2000].

Haycock, Ken. (2003). The Crisis of Canceda's School Lihraries: The Case for Reform and Re-lmestment, Toronto: Association of Canadian Publishers. (Online report). Available at: http:/www.publishers.cal

Hunter, Kaye. (2003). Literature circles and book clubs: variations on a theme. FYI, Winter, 7 (3).

Available at: www.slav.schools.net.au

Krashen, S. D. (1993). The Power of Reading: Insights from the Research, Englewood, ('): Libraries Unlimited.

Krashen, S. (2002). 'Whole Language and the Great Plummet of 1987-92: An Urban Legend from California', (Online Journal) Phi Dela Kappa International.

Available at: www.pdknitl.org/kanpan/k0206kra.htm [Accessed 10th September, 2002].

La Marca. Susan. (Ed.). (1999). Back to books: creating a focus on fiction. Carlton. Victoria: SLAV

La Marca, Susan. (Ed.). (2001). Books up fiont: imesting in the velle of rededing. Carlton, Victoria: SLAV.

La Marca. Susan. (2003). 'An Enabling Adult: The Teacher-Librarian and the Reading Environment' in Breaking Down the Barrers, Papers from the International Association of School Librarianship (IASL) Annual Conference, Durban: South Africa. July.

La Marca, Susan. (2003). An e'nahling adelt: the teacher-lihrarian and the creation of a reading e'nviromment. Ph.D. Thesis. University of Melbourne. Australia.

Last, Marion \& McNamara, Linda. (1999). 'Mini sets at Kew high school' in Susan La Marca (Ed.) Back to books: (reating a focus on fiction (volume 2) Carlton. Victoria: School Library Association of Victoria.

Lonsdale, M. (2003). Impact of School Lihrariess on Studem achierement: a Review of the Resecurch (Online report) Prepared for the Australian School Libraries Association (ASLA) Melbourne: Australian Council for Education Research. Available at: htpp:/www.asla.org.au/rescarch/index.htm

Manguel, A. (1996). A History of Reading. London: Harper Collins.

Massey, Clayton. (2003). The 'no set text approach paper given at the Somerset Conference for Librarians,

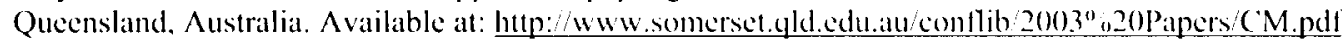
[Accessed February 2003]

OECD. (2000). Reading for Change: Performance and Engagement Across ('oumtries. Results form PISA 2000) Executive summary (Online report) PISA (Program for International Student Assessment). Available at: www.pisal.oecd.org/Docs/Download/ReaddinglixeSummary.pdf

Phillips, J. (1988). Automated or Dedicated: The Image of the School Librarian. Aceess. 2 (3) p. $24-25$.

Rosen, Michael. (1995). Paul Kropp with Wendy Cooling The Receling Solution. Penguin.

Sutherland, Sally. (2003). Wider reading pairs $\langle a$ MCiC: an old idea and a new solution. FYT. Winter, 7 (3). Available at: www.slav.schools.net.au

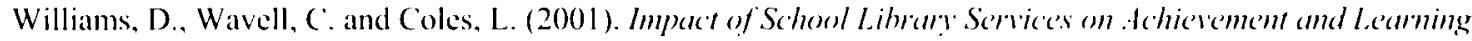
(Litcrature Review) Aberdeen: School of Information and Media. Faculty of Management. Robert Gordon Uni., Council for Museum Archives and Libraries. Available at: http:/www.resource.gov.uk documents/impactsl.pdi

Williams, D., Wavell, C. and Coles, L. (2002). Impact of School Lihruy Senvices on Achievemem and Leaning in Primeny Schesols, Literature Review. Aberdeen: School of Information and Media, Faculty of Management, Robert Gordon Uni., Council for Museum Archives and Libraries. Available at: Www. resource.gov.uk/documents/rmo()4.pdf

Zahnleiter, J. (1985). A Classroom Climate for Literary Response, Atustralican, Jommal of Reading. 8 (4) p. 187 195.

\section{Author Note}

Susan La Marca is a secondary school teacher-librarian. Her doctoral studies at the University of Melbourne focused on attitudinal and contextual factors that influence the role of the teacher-librarian as an enabling adult in creating a reading environment in secondary school libraries. Susan is currently the Publications Officer for the School Library Association of Victoria (SLAV) and editor of their new research journal Synergy. She is an associate editor of the journal Viewpoint: on books for young adults produced at the University of Melbourne and the editor of the books: Back to books. creating a focus on fiction (2 volumes) (1999), Books up front: investing in the value of reading (2001) and Effective learning spaces: inspiration for school library design (2003). At the beginning of 2004 Susan took up a new role as a part time lecturer at the Bendigo Campus of Latrobe University in the School of Education teaching Children's Literature. 